\title{
Japanese Honorific Language in Various Domains
}

\author{
Ely Triasih Rahayu \\ Japanese Literature Study Program, Faculty of Humanities \\ Jenderal Soedirman University \\ Purwokerto, Indonesia \\ hikarinihongo@gmail.com
}

\begin{abstract}
Language belongs to human. In a communication, human as language owner may position themselves as messenger (speaker), message recipient (interlocutor) or as a person who is the object of speech (object of conversation). In Japanese speech community, human must implement their position in communication based on honorific language usage principle. They must proficiently choose language with regard to lexical and grammatical concerns, as well as consider social factor underlying the communication. Expressions human use in Japanese honorific language principle significantly influences the convenience of communication, as the determinant whether or not they are acceptable in the community. This study will analyze Japanese honorific language journey by domains. Honorific language (known as keigo) first appears in the literary work Genji Monogatari. Its language choice and sentence patterns show their difference with common/neutral language, particularly to specialize the language referred to the Emperor. The next domain is family, in which Japanese quite differently calls their own family (uchi) from other's family (soto), but this shifts along with time. The education domain differentiates the language referred to student and teacher. This also takes place in business/office domain, in which language is quite differently used based on one's position in a company. Due to the religious domain, human being as the servants of Allah show their respect to the Creator by praising Allah through a respectful language contained in Al Quran which is translated into Japanese language as the realization of Islamic followers to communicate with Allah (habluminallah).
\end{abstract}

Keywords: Honorific Language, Domain, D Language Choice, Language Marker, Social Factor

\section{INTRODUCTION}

Language serves a genuine function irreplaceable by any other tool, that is, as a means of communication. As a means of communication, language has something to do with human behavior and attitude (Pei, 1963:162).
Language has been used as a barometer of human behavior in society. Ogden and Richards suggest in this case by uttering one of four functions of language, i.e. expressions of attitude to referent (Morris, 1955:70). Therefore, language and its use cannot be observed separately, rather it is always connected to its activity in the society (Wardhaugh, 1986, Matthew, 1997). Based on linguists' opinions, it can be concluded that language in playing its role is highly influenced by human behavior as a social creature to reflect human attitude. Thus, what is spitted from human's mouth which is called as langue is uttered in compliance with the linguistic norms applicable in the society.

In Sociolinguistics, linguistic norms are tigtly related to social factors. Language as a means of conveying (message) to speech partner is interpreted by Sudaryanto (2017:38) as the language which serves the function of maintaining cooperation. This cooperation relationship refers to the horizontal function of language, that is, as the maintainer of cooperation among humans. Humans as the owner of language in this case play the role of message conveyor (speaker/O1) and the message receiver is called as hearer or $\mathrm{O} 2$. It is this concentration which has once been suggested by Kabaya (2009) that a process of communication involves relationship among humans, as speakers or hearers. A speaker is the first person which in Japanese can take the form of boku, ore, watashi, and watakushi and in Indonesia it takes the form $a k u$ and saya in singular context. A hearer is a person which in Japanese can take the form omae and anata and when translated into Indonesian it becomes kamu and anda. Rahayu (2013) adds that a communication agent can be a person which is being discussed and symbolized as O3. In Japanese this can be called as kare (he), kanojo (she) or the pronoun anokata to refer to the reference to someone respected (when translated into Indonesian it is equivalent with beliau). The details of posititonal awareness of a social agent will be studied in the research on the implementation of honorific language in Japanese.

In addition to social agent's positional awareness (hereinafter it will be studied in ningenkankei studies), social or non-language factors (Suwito, 1985:30) are related to those factors beyond language which ground the use of language. In relation to these non-language 
factors, Hymes (1973) suggests the components of speech well-known with their accronym, SPEAKING (scene/setting, participants, ends, act sequence, key, instrumentalities, norms and genres). An expert in Sociolinguistics from Indonesia, Poedjosudarmo (1979) has also explained thirteen components of speech which have been adjusted to the situation of language in Indonesia, particularly in Java. These thirteen components of speech are; (1) speaker's personality, (2) emotional type, (3) speech intention, (4) speaker's perception to hearer, (5) presence of third person, (6) speech tone and situation, (7) speech scene, (8) speech theme, (9) speech facility, (10) speech order, (11) conversational ecology, (12) discourse form, and (13) other linguistic norms. When a comparison is made between Poedjosudarmo's (1979) and Hymes's (1973) opinions, Poedjosudarmo seems to emphasize more on speech participant aspect. This can be seen from several aspects of speech participants which are stated in a row namely speaker's personality, emotional type, speech intention, perception to hearer, and presence of third person. Meanwhile, Hymes (1973) seems to give more emphasis on speech setting, which constitutes a component with insignificant influence on speech form. Hymes views topic of speech as the center of speech act while Poedjosudarmo (1979) deems topic of speech merely as one of speech components whose role is mainly influenced by other speech components by incorporating speech scene as one speech component, something which Hymes places beyond speech components together with speech situation

The language which has something to do with human's social behavior based on the linguistic norms in Japanese speech community by taking into account the non-language factors above will be studied in this research, given the scope of Japanese Honorific Language study based on time sequence.

The speech community with linguistic norms existing in Japanese will be studied using the data in the form of dialogs or utterances containing Japanese honorific language marker. The data are taken from Japanese honorific language studies literature and Al Quran translated in Japanese language. This research is qualitative since the research does not study numbers which relate to population, while its study is descriptive in nature.

\section{CHARACTERISTIC OF JAPANESE HONORIFIC LANGUAGE}

The linguistic norm which governs the use of Japanese language lies in keigo studies. Keigo is a Japanese term which refers to honorific language. The term keigo is related to a speaker's positional awareness in communicating with his/her hearer. This speaker's positional awareness has something to do with the relationship between the communication agents, where the communication is made, content or theme of discussion, and form of speech (Kabaya,2009:3). When the hearer is a leader, then the speech will be different from when the speech is addressed to a peer. The speech form at the office or receptionist will be different from that in market or beach. A speaker utters more formal utterances when the theme being discussed is politic or education as compared to when they talk about hobbies. Communication will run smoothly when the agents are aware of their own positions and play their roles properly according to their positions by choosing the appropriate language. The choise of using formal language will of course be weird when the communication agents talk about their hobies on a beach. On the contrary, a company's leader will find it inconvenient when his/her staff provides an explanation of their production using non-formal language in a meeting. Kabaya (2009:3) formulates a communication situation in this honorific language domain by detailing the communication variables into two variables in Japanese term, i.e. ningen kankei (人間関係) and $b a$ (場) as shown in the following chart;

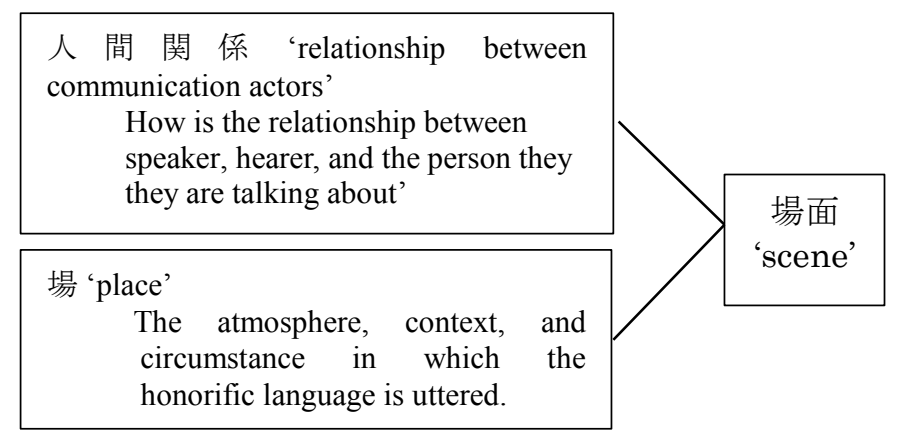

Chart 1. Communication Variables (Kabaya, 2009:3)

The following illustrations depict the process of communication based on how the relationship between speakers, hearers, and the person they are talking about (ningenkankei) in office domain is.

A subordinate $(\mathrm{O} 1)$ will exalt his/her superordinate $\mathrm{O} 2$ as a hearer using respecful language $(\mathrm{R})$.

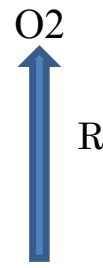

$\mathrm{O} 1$

- A subordinate $(\mathrm{O} 1)$ when communicating with $(\mathrm{O} 2)$, will exalt his superordinate $(\mathrm{O} 3)$ as a pokok pembicaraan. 


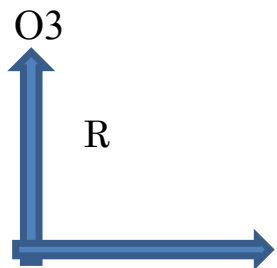

$\mathrm{O} 2$

O1 N

- A subordinate (O1) will humble himself/herself to respect his/her superordinate using humble language (H).

$\mathrm{O} 1$

$\mathrm{H}$

$\mathrm{O} 2$

- An employee (O1) will use neutral language $(\mathrm{N})$ with no form of honorific language when communicating with their fellow employees (O2) on an equal position/level. Similarly, a superordinate (O1) will use neutral language netral $(\mathrm{N})$ with no form of honorific language when communicating with his/her subordinates $(\mathrm{O} 2)$.

$\mathrm{O} 1$ $\mathrm{O} 2$

$\mathrm{N}$

Keigo constitutes the respect language used in a formal situation, addressed to respect others. Keigo consists of sonkeigo, i.e. the language used to exalt other's acts or conditions; kenjougo, i.e. the language used to humble the speaker's acts or circumstance in order to respect others; and teineigo, i.e. the language used in formal situation (teineigo has definite marker, the copula desu and $\sim$ masu).

\section{1) Sonkeigo}

Basically, sonkeigo is the language used to respect others (the hearer or the person being discussed) (Kikuchi,1998; Kabaya, 2009; Kabaya,2010). Suzuki (1998:23) suggests that sonkeigo is:

尊敬語は、上役の人、上司、先輩、 初対面の人、年齢の上の人、お客

様に対して、その動作や状態など に、敬意を表す言葉づかいです。

Sonkeigo wa, jouyaku no hito, joushi, senpai, shotaimen no hito, nenrei no ue no hito, okyakusama ni taishite, sono dousa ya joutai nado ni, keii o arawasu kotoba zukai desu. 'Sonkeigo is the respect language to express respect towards a person with higher position, towards superordinate, senior, a person met for the first time, and towards customers.'

The number of sonkeigo lexical markers is limited (Kikuchi,1996:2; Suzuki,1998:28; Kaneko,2010:168; Kabaya,2010:18-19;). The sonkeigo lexical markers, according to Kikuchi, in his work Keigo nyuumon (1996:23) are presented in the following table.

Table 1. Lexical Forms of Sonkeigo Marker

\begin{tabular}{|c|c|c|}
\hline Jishokei & Sonkeigo & Meaning \\
\hline \begin{tabular}{|l|} 
する \\
suru
\end{tabular} & $\begin{array}{l}\text { なさる } \\
\text { nasaru }\end{array}$ & to do \\
\hline $\begin{array}{l}\text { くれる } \\
\text { kureru }\end{array}$ & $\begin{array}{l}\text { くださる } \\
\text { kudasaru }\end{array}$ & to receive \\
\hline 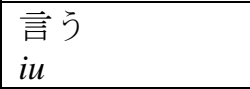 & $\begin{array}{l}\text { おっしゃる } \\
\text { ossharu }\end{array}$ & to say \\
\hline $\begin{array}{l}\text { 来る・行く・ } \\
\text { いる } \\
k u r u \cdot i k u \cdot i r u \\
\end{array}$ & $\begin{array}{l}\text { いらっしゃる } \\
\text { irassharu }\end{array}$ & $\begin{array}{l}\text { to come } \cdot \text { to } \\
\text { go } \cdot \text { to be present }\end{array}$ \\
\hline $\begin{array}{l}\text { 見る } \\
\text { miru }\end{array}$ & $\begin{array}{l}\text { ご覽になる } \\
\text { goran ni naru }\end{array}$ & to see \\
\hline $\begin{array}{l}\text { 食べる・飲む } \\
\text { taberu・nomu }\end{array}$ & $\begin{array}{l}\text { 召し上がる } \\
\text { meshiagaru }\end{array}$ & to eat $\cdot$ to drink \\
\hline $\begin{array}{l}\text { 知っている } \\
\text { shitteiru }\end{array}$ & $\begin{array}{l}\text { ご存知 } \\
\text { gozonji }\end{array}$ & to know \\
\hline
\end{tabular}

The morphological forms as sonkeigo markers are o/go ni naru, $\sim$ (ra)reru, go nasaru (Kikuchi,1996; Kaneko,2010; Kabaya,2010). Not all verbs can be applied to with this pattern when they are to be changed into their sonkeigo forms. For example, the sonkeigo form of the verb miru 'to see' is not omininaru, rather it shall be goran ni naru or mirareru. Yet such words as kaku 'to write', уоти 'to read', denwa/megane o kakeru 'to make a call/to wear glasses', will tuse the pattern o-ni naru, thus they become okaki ni naru, oyomi ni naru, o denwalo megane o kake ni naru. Those words use the prefix obecause they come from wago 'Japanese way of reading'. On the other hand, the words kango 'Chinese way of reading' use prefix go- and the pattern go-ni naru such as the words kinyuu suru 'to fulfill' and houkoku suru 'to broadcast' which would be gokinyuu ni naru and gohoukoku ni naru. In Japanese, there is no such system which explain what verbs can use the pattern o/go ni naru or $\sim(r a) r e r u$. The last morphological marker 
sonkeigo is go-nasaru. For example, the verb futsuukei kinyuu suru 'to fulfill' will become a verb sonkeigo kinyuu nasaru or gokinyuu nasaru, with the following study (Kabaya, 2010:20):

\section{2) Kenjougo}

Kenjougo is the act of humbling oneself done by the subject or the speaker (Kikuchi,1996). The goal aimed by someone who expresses language in kenjougo 'language to humble oneself' is to respect the hearer or the person being discussed. The difference of sonkeigo from kenjougo is that the language used in sonkeigo is the one to exalt others and the language used in kenjougo is the language of humbling oneself. However, both sonkeigo and kenjougo share the same goal, i.e. to respect the hearer the person being discussed.

Kaneko (2010) gives some examples of kenjougo vocabulary in the table below and terms this kenjougo as "watashi ga" 'I'. The term "watashi ga" here is intended to indicate that kenjougo is addressed to oneself or it can also be used to express a language for one family/oneself. The kenjougo lexicals are highly limited as shown in the following table.

Table 2. Kenjougo Marker Lexicals

\begin{tabular}{|c|c|c|}
\hline Jishokei & Kenjougo & Meaning \\
\hline $\begin{array}{l}\text { 行く } \\
i i k u \\
\text { 来る } \\
\text { kuru } \\
\text { いる } \\
r u \\
\end{array}$ & $\begin{array}{l}\text { まいります } \\
\text { mairimasu } \\
\text { おります } \\
\text { orimasu }\end{array}$ & $\begin{array}{l}\text { to go } \\
\text { to come } \\
\text { to be present }\end{array}$ \\
\hline $\begin{array}{l}\text { 言う } \\
i u\end{array}$ & $\begin{array}{l}\text { もうします } \\
\text { moushimasu } \\
\text { (人に)もうしあげます } \\
\text { (hito ni) moushiagemasu }\end{array}$ & to say \\
\hline $\begin{array}{l}\text { 見る } \\
\text { miru }\end{array}$ & $\begin{array}{l}\text { 拝見します } \\
\text { Haikenshimasu }\end{array}$ & to see \\
\hline $\begin{array}{l}\text { 飲さ } \\
\text { nomu } \\
\text { 食べる } \\
\text { taberu }\end{array}$ & $\begin{array}{l}\text { いただきます } \\
\text { Itadakimasu }\end{array}$ & to drink \\
\hline $\begin{array}{l}\text { 知っている } \\
\text { shitteiru }\end{array}$ & $\begin{array}{l}\text { もの をぞんじており } \\
\text { ます/知っております } \\
\text { mono } \\
\text { ozonjiteorimasu/shitteorim } \\
\text { asu } \\
\text { 人を ぞんじあげて } \\
\text { おります } \\
\text { hito ozonjiageteorimasu }\end{array}$ & to know \\
\hline $\begin{array}{l}\text { 思う } \\
\text { omou }\end{array}$ & $\begin{array}{l}\text { ぞんじます } \\
\text { zonjimasu }\end{array}$ & to think \\
\hline $\begin{array}{l}\text { する } \\
\text { suru }\end{array}$ & $\begin{array}{l}\text { いたします } \\
\text { itashimasu }\end{array}$ & to do \\
\hline $\begin{array}{l}\text { あげる } \\
\text { ageru }\end{array}$ & $\begin{array}{c}\text { さしあげます } \\
\text { sashiagemasu } \\
\end{array}$ & to give \\
\hline $\begin{array}{l}\text { もらう } \\
\text { morau }\end{array}$ & $\begin{array}{l}\text { いただきます } \\
\text { itadakimasu }\end{array}$ & to receive \\
\hline $\begin{array}{l}\text { あう } \\
a u\end{array}$ & $\begin{array}{l}\text { お目にかかります } \\
\text { o me ni kakarimasu }\end{array}$ & to meet \\
\hline $\begin{array}{l}\text { きく } \\
k i k u \\
\end{array}$ & $\begin{array}{l}\text { うかがいます } \\
\text { ukagaimasu } \\
\end{array}$ & to listen \\
\hline
\end{tabular}

The kenjougo sentence is formed by adding the prefix o/go- followed by the $\sim$ shimasu/moushiagemasu form verb marker. Below is the example of of vocabulary change of futsuukei form into kenjougo form.

Table 3. Morphological Form of Kenjougo Markers

\begin{tabular}{|l|l|l|}
\hline \multicolumn{1}{|c|}{ Jishokei } & \multicolumn{1}{c|}{ Kenjougo } & Meaning \\
\hline 買う & $\begin{array}{l}\text { お買いします } \\
\text { kau }\end{array}$ & to buy \\
\hline $\begin{array}{l}\text { kaishimasu } \\
\text { kiku }\end{array}$ & $\begin{array}{l}\text { お聞きします } \\
\text { okikishimasu }\end{array}$ & to listen \\
\hline $\begin{array}{l}\text { 㶳く } \\
\text { kaku }\end{array}$ & $\begin{array}{l}\text { お書きします } \\
\text { okakishimasu }\end{array}$ & to write \\
\hline $\begin{array}{l}\text { 待つ } \\
\text { matsu }\end{array}$ & $\begin{array}{l}\text { お待ちします } \\
\text { omachishimasu }\end{array}$ & to wait \\
\hline $\begin{array}{l}\text { 立つ } \\
\text { matsu }\end{array}$ & $\begin{array}{l}\text { お立ちします } \\
\text { otachishimasu }\end{array}$ & to stand \\
\hline $\begin{array}{l}\text { 飲む } \\
\text { nomu }\end{array}$ & $\begin{array}{l}\text { お飲みします } \\
\text { onomishimasu }\end{array}$ & to drink \\
\hline $\begin{array}{l}\text { 読む } \\
\text { yomu }\end{array}$ & $\begin{array}{l}\text { お読みします } \\
\text { oyomishimasu }\end{array}$ & to read \\
\hline $\begin{array}{l}\text { 呼ぶ } \\
\text { yobu }\end{array}$ & $\begin{array}{l}\text { お呼びします } \\
\text { oyobishimasu }\end{array}$ & to call \\
\hline
\end{tabular}

\section{3..... Teineigo}

The teineigo form is 'polite language' or in Japanese it is defined as bunzentai o teineina kanji ni suru 'a sentence the entirety of which shows polite language' (Kaneko, 2006:23). This form is characterized by masu and desu. David (2009) calls the teineigo form as formal language. Masu is a suffix for a verb and serves as a formal utterance marker. The masu changes are varied, for example, being adjusted with the past time marker it will be mashita. Masu can also change into masen (negative teineigo marker) and masen deshita (negative teineigo marker of past sentence).

\section{A HiSTORICAL STUDY OF REFERENT HONORIFICS IN JAPANESE (NAGATA, 2006)}

Keigo in Japan was born since 13th Century along with time. During early 13th Century, the powers were with some rulers in Japan, rather than being focused on only one ruler. Approaching the 7th century, the power began to get concentrated once again on one ruler, i.e. tennou 'emperor', and the applicable government regulations called as ritsuryou 'legal regulations' were still adopted from Chinese model, and at that time the Japanese writing system had not existed yet. This continued until the 12th century. During the Nara period 
(710-794) Japanese literature began to exist even if it was still adopted from China.

During the Heian period (794-1192), the kana ${ }^{4}$ 'Japanese' letter which derived from the Chinese letter writing characters began to be introduced in Japan. Genji Monogatari 'Tale of Genji', one of well-known Japanese literature, was written around the 11th century. This Tale of Genji was a collection of life and romance tales of a famous kingdom prince named Genji. In this tale, the respect language had began to be used based on social context factors, such as status level and relationshop factors.

When the ritsuryou 'legal regulations' were in effect, all regional powers were centralized in the central government of each region. At the same time, kuge appeared which constituted a religion- and nobility-based power. It was from this on that the feodal system government began to come in force. In the 12th century, samurai, buke or bushi declared that there were two powers, namely the powers under Genji and Heike. When Genji won the battle for power, Genji established a military power system from the samurai caste which was called as shogun during their reign in 1192.

Based on the Heike's story, the tale of Heike was published which told a story about the fall of this tribe in narrative. The dialogs and quotes in Heike revealed many respect language/keigo .

During Muromachi period (1336-1573), kyougen $^{5}$ 'theater' was born and could be enjoyed by more commoners, and noh 'puppet theater' were mostly enjoyed by nobles. In kyougen 'theater' the use of keigo based on social context were common.

After the fall of Shogun Ashikaga era in 1537, Japan underwent a vacuum of power until 1590. In 1590, Hideyoshi began to build new government with his focus on the national politic and economic development. The outstanding success was manifested only when the the shogun Tokugawa government and central government moved to Edo (now Tokyo) in 1603.

During the Hideyoshi government era, Japan began to build their relations with Korea and this relationship continued until a book which was written as the basis or instruction regarding the trade with Korea was published. This book provided an explanation how the respect language should be used in order to give positive impression to the speaker. At the end of Edo period, an official language began to be established.

In 1635, Japan closed itself (isolation politic) and only in 1853 did Japan begin to open itself for US military power. The Edo government (1603-1868) started to lose its power and in 1867 began a restoration. This government restoration era was called Meiji era or period.

During Edo period, the language was determined heavily by regions or territory, hence everyone spoke with their own dialects. During the Meiji period, the country was based on democracy system. Every citizen was the citizen of Japan with a language everyone can understood, namely the national language. The Meiji government reigned for 45 years, and followed by the taishou period for 15 years (1912-1926), then the shouwa period for 65 years (1926-1989).

In 1945, Japan lost against the Allied troops (US, England, Netherland and China alliance). After this defeat, Japan witnessed massive changes in their social and language fields. It was during this era that the social hierarchi was born, which showed notable gap between the rich and the poor. The rich farmers controlled most lands and hired their poor counterparts. However, after the World War II, when all agricultural lands were taken over by the Alliance, there was no social status gap among Japanese farmers or people anymore. They shared the same financial losses. In turn, this eliminated the insofar existing social hierarchy, thus the use of keigo was no longer based on social status and its function had shifted.

The influence of Confucianism had led the Japanese people to think even further. The use of keigo was based more on age difference factor, the respect utterance was addressed to older people. In 1986, Japanese women began to have the equal opportunity at work. This had some influence on the respect language based on gender. Women tend to use more respect language than men.

Bilingualism, in this case between the regional and national languages, also influenced the use of keigo. When the two language were mastered, the keigo system in each regional dialect would vanish when they master the national language.

Since World War II, the use of keigo had shifted its function. Keigo tended to be used in business communication. Keigo shows the shift from an absolute system into relative one, as suggested by Tsujimura (1971) which is quoted from Nagata's work (2006:12); The shift from an absolute honorific expression system to a relative honorific expression system cannot be neglected in the history of Japanese honorifics.

An example of this shift from absolute keigo system to the relative one is the use of word father. When a kid calls his/her father, he/she will use the word otousama, yet when he/she is talking with others, he/she will refer to his/her own father as chichi.

The conclusion which can be drawn from this explanation is that keigo system began from a Japanese literature, i.e. the Tale of Genji which was adopted from China. Since keigo at that time was used within the kingdom, it is then obvious that the use of keigo was based on social context in the form of relationship of social status between the Kingdom's members and commoners. As the time went, keigo was used based on social status within the government. There were different language variations between the government and the people. In essence, what is in common between the past and present use of keigo is that it is a respect language used based on social status difference factor. 


\section{Japanese Honorific Language in Literary Work}

According to the history, the use of Japanese honorific language (keigo) shifts based on community's condition, which is influenced by the community's position. Keigo starts to develop when it is used in literary work, in which based on the spoken subject, certain dictions are available to, for example, exalt a king or to lower common people. Keigo in literary work is initiated in Genji saga. Below is a quote of Genji saga which contains keigo expression.

1）どの帝の御代のことであったか、女御 や更衣たちが大勢お仕えなさっていた なかに、たいして高貴な身分ではない で、きわだって御寵愛をあつめていら つしやる方があった。

Dono tei no mivo no kotodeatta ka, nyōgo ya kōi-tachi ga taisei otsukaenasatteita naka ni, taishite kōkina mibunde wanaide, kiwadatte gochōai o atsumete irassharu kata ga atta.

The sentence above contains the word miyo (御代) which means era/time/period, referring to the governance era/time/period of an emperor (帝). The writer of Genji saga chooses the word miyo (御代) to show his respect to the governance period of Japanese emperor (天皇の治世).

The keigo marker in the word miyo (御代) lies on the kanji 御 which is pronounced go. 御 simultaneously serves as the prefix of a noun as well as to change a noun from its neutral form to honorific form. The kanji letter may be pronounced Go- as well as O-, which equally serve to change a noun from its neutral form to honorific form like the following sentence.

2) 帝はお心にうなずかれるところがおあ りであった。かねて若宮を、親王にな さらなかったのも、深いお考えのある ことだった。

Tei wa okokoro ni unazuka reru tokoro ga o arideatta. Kanete Wakamiya o, shin'nō ni nasaranakatta no mo, fukai okangae no aru kotodatta.

The honorific marker of prefix $\mathrm{O}$ - in the above quote is located on the word okokoro 'heart' (お心). This word refers to the emperor's heart, thus the writer pays his respect by adding the prefix $\mathrm{O}$-. The same prefix is added to the word okangae (お考え) 'mind'.

In the Japanese linguistic morphology, not all nouns may be changed to keigo form by adding the prefixes, in which case no system regulates which noun may be added with prefix o or go. However, these prefixes cannot be added to loanwords, thus all loanwords are neutral. Loanwords, for example hoteru (hotel), penshiru (pencil) and borupen (ballpoint), cannot be changed to their honorific form using prefix O- or Go(御). Prefixes O- and Go- are differentiated in their usage, in which prefix $\mathrm{O}$ - is used for words pronounced using wago pronouncing method (Japanese pronouncing method) while prefix Go- is used for words pronounced using Kango pronouncing method (Chinese pronouncing method).

Back to the data number 1, besides using keigo on nouns, honorific verb is also found in Genji saga. The honorific verb is identified on the word nasatteita (なさ つていた) 'to do, perform a work'. The concerned work is shown by the object which accompanies the word nasatteita (なさっていた), the word otsukae (お仕え) 'servie', which is derived from the noun tsukae (仕え) added with prefix $\mathrm{O}$ - (お), intended to change the form of noun tsukae to its respectful form, thus the expression otsukaenasatteita (お仕えなさつていた) becomes an honorific expression. This expression is referred to the subject of the sentence, nyōgo ya kōi-tachi (女御や更衣 たち), who is the woman who serves the emperor.

Another verb found in the quote of Genji sage which shows honorific language is irassharu (いらつし やる), as a word which follows the verb atsumete 'to collect' (あつめて). The verb irassharu in its sole form bears the meaning to exist, but in this sentence the verb irassharu serves as a tense marker followed by the verb form $\sim$ te (showing progressive form). This imasu form is the one which changes the common/neutral/teineigo expression, as it is changed to its honorific form, to irassyaimasu, thus the common or neutral/teineigo form of atsumete irassyaimasu in the above sentence is atsumete imasu. The writer of this saga chooses the honorific form of the word 方 'person' to replace the word 人 hito 'person' as a neutral word.

\section{Japanese Honorific Language in Family Domain}

The use of Japanese honorific language in family domain may be easily identified in calling each family member. A person will differently call his own father and mother with other's father and mother, as shown in the chart of Kaneko (2010), quoted from the book Nihongo Keigo Toreeningu. For example, when someone is calling. 


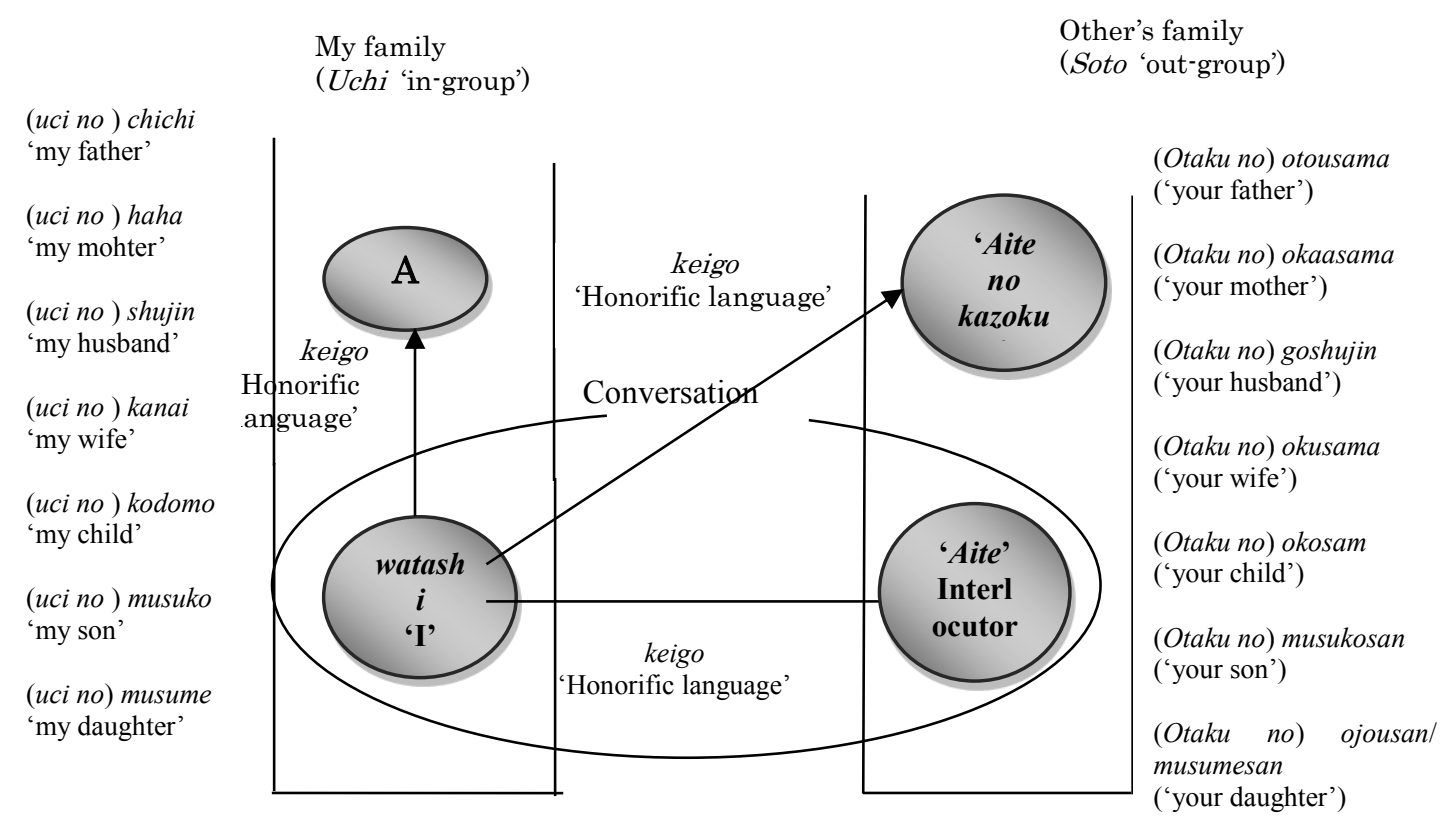

Chart 1. Uchi-soto

We may view in the chart that according to Japanese honorific calling system, we will differently call our own family from other's family. This is uchisoto system. Uchi refers to our own family, thus uchi may be translated into in-group and soto as out-group. The chart may be implemented in the following telephone conversation.

3) A: moshimoshi, konnichiwa.

Hello, good day.

B: moshimoshi, konnichiwa.

Hello, good day.

A: Kinjou no Tanaka desuga, Okaasan wa irassyaimasuka.

I'm Tanaka, your neighbor. Is the mother at home?

\section{B: Haha wa sakkihodo dekaketandesuga. Mother just left.}

The conversation proves that when the caller asks about the mother, he uses okaasan, but the receiver uses the word haha. The caller uses the word okaasan as an honorific form to call the Mother (B's Mother) who bears soto position, while the concerned Mother is called by haha because of her uchi position.

This calling system currently shifts, in which a child calls his mother okaasan even in an uchisoto conversation. This is current phenomenon of call shifting for family (relatives) in Japanese family system.

In the current Japanese family domain, children tend to talk to their parents using general language. Some surveys show that there is no difference in the language used by children to their parents and that used to their friends. This is a phenomenon of language shift used by children to their parents. However, two generations before them (current children) often use keigo in conversation between children with their mother (their grandgrandfather/grand-grandmother) and conversation between wife and husband. Japanese parents confirm that they do not feel that their children do not pay respect to them with this use of general language. They tend to feel closer and no gap, thus their children are more open to their parents.

Honorific language expressions are also quite obviously found in welcoming guest during a visit. The host will greatly pay attention to each of his words in order to pay respect to the guest. It is a habit of Japanese family to pay respect to a visiting guest. Below is an example of expression when a host lets his guest in.

"Douzo oagari kudasai" 'Please come in'. The host's expression to let his guest in has a respectful language marker in the use of prefix $O+$ Verb renyoukei ${ }^{l} ; O+$ agari.

There is a habit in Japan that people get into house using surippa 'slippers'. Thus, when a guest arrives, the host will let the guest use the surippa in an expression, "Surippa o ohaki kudasai" 'Please wear the slippers'. The

\footnotetext{
${ }^{1}$ Renyoukei is a verb form which is formed by removing the suffix $\sim$ masu from teineigo (polite form). For example, the basic form of verb iku 'to go' when changed to the form $\sim$ masu will become ikimasu. The verb renyoukei will remove the suffix $\sim$ masu, which will then become $i k i$. Equally, the word yomimasu 'to read' will become yomi, kaki 'to write' will become kaki. For certain words, respectful language may be formed by adding prefix $\mathrm{O}$ followed with verb renyoukei.
} 
honorific language is shown on the word ohaki of which formation system is equal to that of the word oagari.

Another case is the expression used by a host to let a guest try the cakes served. The neutral form of the word eat is taberu, but in order to pay respect to the guest, the host will use a special formed word which bears meaning to eat, meshiagaru. The expression will be "douzo okashi wo meshiagattekudasai" "Please eat this cake'. Meshiagatte kudasai is an imperative far politer than tabetekudasai.

\section{JAPANESE HONORIFIC LANGUAGE IN EDUCATION}

Keigo (Japanese honorific language) is taught in national language subject (Kokugo). Kokugo is taught since elementary school, which also contains honorific language (keigo) material. The implementation of this keigo study may be found in conversation between student and teacher, for example, when a student asks about the teacher's home.

\section{4) Student : Sensei no otaku wa dochira desuka.}

Mom, where is your home?

We may find here lexical selection of honorific form word on otaku 'home' and dochira 'where' to replace the words $u c h i$ and doko which are neutral. The two words are used by the student to pay respect to the teacher. Below is an example of respectful form by exalting the verb referring to the teacher.

\section{5) Student : Sensei, ryuugakusei no soubetsukai ni koraremasuka. \\ Mom, will you attend the foreign students' farewell party?'}

The verb koraremasu above is an honorific verb referring to the teacher's action. The student chooses the word koraremasu in order to exalt the teacher's action. The word ends with a question tag $k a$, which is one of interrogative sentence markers in Japanese language.
6) Student : Kinou Suzuki sensei ni odenwa itashimashita. Kyou wa gogo $2 j i$ ni au yakushoku shimashita. I called Mrs. Suzuki. We have an appointment at $2 \mathrm{pm}$ today.

The humble form is shown on the verb odenwa itashimashita 'has called'. According to the tense, the calling activity has been done (with past tense marker of suffix $\sim$ mashita). The humble form is marked with prefix $\mathrm{O} \sim$ and the word itashimashita 'to do' (verb with humble form marker) by referring to the word denwa which bears the meaning of call.

A common mistake in a class where interactions between student and teacher takes place occurs when a student has not understood what the teacher has taught. The student asks the teacher to repeat what he has taught, in which the expression "sensei, mou ichido itte kudasai" 'sir, please repeat once more' is often used by student although it has less polite sense. The word itte kudasai is an imperative to repeat something that has just been conveyed. In consideration of teacher and student's positions and the intention of student's speech (which is to command), the student's sentence should be polite. The correct expression should be "Sensei, mou ichido ossyatte kudasai." Ossyatte is a verb of respectful language chosen to show student's respect to his teacher.

\section{JAPANESE HONORIFIC LANGUAGE IN OFFICE (BUSINESS) DOMAIN}

The researcher has performed a survey by distributing questionnaires and interviewing 134 Japanese native speakers as the respondents. $93 \%$ of the respondents states that they use Japanese honorific language (keigo) in office (business) domain. They also add that they infrequently use keigo with their family members; between children and parents and between husband and wife. Keigo is implemented at their office to pay respect to their superior or customer from other company. Below is an example of keigo used between a staff and the manager via email.

7) Staff:

田中部長

お世話になります。

13 日 7 月 (木)の生産レポートを添付し ていますので、

\section{ご確認お願いいたします。 \\ Tanaka Buchou}

Osewaninarimasu.

Juusan nichi shichi gatsu (moku) no seisan repooto o tenpushiteimasunode, gokakunin onegaiitashimasu.

Manager Tanaka

I'm sorry to bother you,

Enclosed in the attachment is the production report dated Thursday, July 7.

Please check.

In the e-mail sent by the staff to the manager, there are two keigos; gokakunin and onegaiitashimasu. Gokakunin is a respectful form language in the pattern of prefix Go + noun (go+kakunin) and onegaiitashimasu is a humble form language with verb marker of itashimasu.

The implementation of keigo in business world is often found in advertisement, such as that in newspaper, in order to pay respect to the readers, with an expectation that they will become costumer. An example may be found in the advertisement expression which aims at influencing 
readers to register to asahi shinbun digital (Asahi Shinbun Dejitaru no Moshikomi wa Kochira). On the page, the writer expects that readers will digitally register to asahi newspaper. Below is a quote from the concerned sentence.

8）朝日新聞デジタルがビジュアルや切り口 にこだわったスペシャル企画をまとめて ご紹介します。

Asahi shinbun degitaru ga bijuaru ya kiriguchi ni kodawatta supesyaru kikaku o matomete goshoukai shimasu.

Asahi Shimbun Introducing special projects that digital is particular about visuals and performance.

The writer persuades readers using humble language, as shown in the use of the words goshoukai shimasu 'to introduce.' The humble marker or form pattern is prefix go+shoukai + shimasu (pattern go+ +shimasu).

\section{JAPANESE HONORIFIC LANGUAGE WITHIN RELIGIOUS DOMAIN}

The analyzed translation of Al Quran from Arabic to Japanese language is that translated by Ryoichi Mita whose Moslem name is Umar Mita. Umar Mita is the second president of Japanese Muslim Association after Sadiq Imaizumi. After 12 years translating Al Quran into Japanese language, it was finally published on June 10, 1972.

In Islamic religion, human beings are recommended to speak the language based on the following verse:

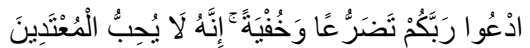

Ad'uu rabbakum tadharra'awwakhufyah. Innahuu laa yuhibbul mu'tadiin.

'Call upon your Lord in humility and privately: indeed, He does not like transgressors. ' (Al-A'raaf: 55)

One implementation of meaning contained in Surah Al A'raaf is the use of polite language as mentioned in that Japanese Al Quran translation. Due to the religious domain, the forms of respectful language will be discussed as the human beings' expressions to praise God. The Japanese Al Qur'an translation to analyze its honorific language is the translation of Surah Al Ikhsan (76) verse 9 and 11 .

Surah Al Ikhsan (76) verse 9,

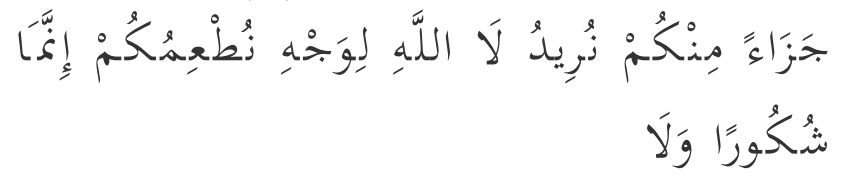

Japanese translation;

9)（そして言う。）「わたしたちは，アッ ラーの御喜びを願って，あなたがたを養 い，あなたがたに報酬も感謝も求めませ h。

(Soshiteiu. ) 'Watashi-tachiwa, arrā no o yorokobi o negatte, anatagata o yashinai, anatagatanihōshūmokanshamomotomemasen

English Translation;

[Saying], "We feed you only for the countenance of Allah. We wish not from you reward or gratitude.

The Qur'an Chapter Al Ikhsan verse 9 contains the use of prefix $O$ - followed with the word yorokobi (喜 び). The word yorokobi has the meaning that the blessing refers to Allah blessing that the word is given the prefix ointended to praise Allah. In Surah Al Ikhsan verse 11, Allah is praised by changing verbs into the forms of respectful language.

of Surah Al Ikhsan (76) verse 11,

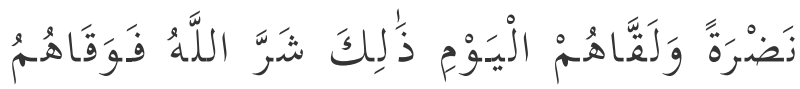

Japanese Translation;

10) それでアッラーは，その日の災厄からか れらを守り，素晴しい喜びを与えられる。 Sore de arrāwa, sonohi no saiyakukarakarera o mamori, subarashīyorokobi o ataerareru.

English Translation;

So Allah will protect them from the evil of that Day and give them radiance and happiness.

Due to Surah Al Ikhsan verse 11, there are some forms of respectful language, that is in the word ataerareru (与えられる). The meaning of the word ataerareru (与えられる) is 'to give'. The verb gives the verse an object of yorokobi 'happiness'. The happiness here is directly given by Allah that the verbal forms used are the forms of respectful language with the pattern marker $\sim$ rareru on verb ataerareru (atae+rareru). 


\section{CONCLUSION}

Japanese honorific language or known as keigo first appears in Genji Monogatari (Genji Saga) in the $11^{\text {th }}$ century. The honorific language is used to pay respect to the Emperor and his family. Thus, we may conclude that honorific language (keigo) is first used in Japan in literary work.

Honorific language is also used in family domain, in which a wife uses it referring to her husband and a child uses it referring to his parents in order to pay respect to either of them through honorific language choice. This family domain is where uchisoto system appears, referring to how to call. Uchi means individuals of one's own family and soto means individuals beyond one's family (other's family). A person will differently call his own family from other's family. For example, otoosan 'father', okaasan 'mother' and goryoushin 'your family' are used by someone to call other's family, while chichi, haha and kazoku will be used to call his own family. As time goes by, there is a shift of how people use honorific language in family domain. Wives and youngsters currently do not use honorific language (keigo) in their communication with their husband and parents respectively.

In education domain, a student will choose polite language to communicate with his teacher. This also takes place in business or office domain. A subordinate will use respectful language to his superior; however, a superior will only use common/neutral language to his subordinate. Respectful language is obviously used when a company conducts a marketing activity with its customers. Newspaper and television advertisement and announcer at public place will certainly use respectful language to exalt customers. Due to the religious domain, Surah Al A'raaf mentions that human beings should pray in polite language, as shown in Surah Al Ikhsan verse 9 and 11. In this verse there is the use of prefix $0 \sim$ preceding the noun and the pattern of $\sim$ rareru on verbs as the praising forms of the conducts made by Allah, the Creator.

\section{References}

Ely Triasih Rahayu. (2013) "Sistem dan Fungsi Tingkat Tutur Bahasa Jepang dalam Domain Perkantoran", Dissertation, Universitas Sebelas Maret

Hymes, Dell, ed. 1973. Foundations in Sociolinguistics An Ethnographics Approach. Philadelpia: University of Pennsylvania Press

Kabaya , Hiroshi. et all. 009. Keigo Hyougen. Tokyo: Taishukan

Komyunikeeshon.Tokyo: Asakura 2010. Keigo

Kikuchi,Yasuto. 1996. Keigo Nyuumon.Tokyo: Maruzen

Matthews, Peter. 1997. The Concise Oxford Dictionary o Linguistics. Oxford:Oxford University Press

Morris, Charles, 1955. Signs, Language and Behavior.
New York: George Braziller,Inc

Nagata, Takashi. 2006. A Historical Study of Referent

Honorifics in Japanese. Tokyo: Kabushiki Kaisha Hituzishoboo

Pei, Mario,1963. The Story of Language. New York: A Mentor Books, The New American of World Literature,Inc

Poedjasoedarma, Soepomomo Dkk. 1979. Tingkat Tutur Bahasa Jawa. Jakarta: Pusat Pembinaan Dan Pengembangan Bahasa Departemen Pendidikan Dan Kebudayaan

Sudaryanto,2017. Menguak Tiga Faset Kehidupan Bahasa.Yogyakarta:Sanata Dharma University Press

Suwito.1985a. Pengantar Awal Sociolinguistics, Teori dan Problema. Surakarta: Kenary Offset. 1985b. Sosiolinguistik. Surakarta: Henary Offset.

Suzuki, Yukiko. 1998. Utsukushii Keigo no Manaa. Tokyo: Miryoku Bijutsu.

Wardhaugh, Ronald. 1986. An Introduction to Sociolinguistics. Oxford: Basil Blackwell. 